Dossier: Conference of Medellín: 50 years - Original Article (c) 8

\title{
CELAM and the emerging reception of the "Bridge Theology" of Pope Francis: from Marcos Gregorio Mcgrath to the Latin American church today
}

\author{
O CELAM e a recepção emergente da Teologia da Ponte do Papa Francisco: \\ de Marcos Gregório McGrath à Igreja latino-americana hoje
}

Robert S. Pelton, C.S.C.

\begin{abstract}
The Second Vatican Council has a special significance in Latin America. This is especially true due to the influence of the document Gaudium et Spes (The Church in the Modern World). This took place at the Medellín Conference (1968) when Bishop Marcus Gregorio McGrath, C.S.C., pointed to this influence through his keynote address "The Signs of the Times." He was prepared for this moment through his earlier theological training in Europe and his pastoral missions, especially in Chile and Panama. It was his earlier practice of Catholic Action among young lay persons that led him into the "bridge theology" that was to be promoted further by Pope Francis.
\end{abstract}

Keywords: Bridge Theology; Laity; Vatican Council II; CELAM; McGrath, C.S.C.

\section{Resumo}

O Concílio Vaticano II possui um significado especial na América Latina, o que se justifica especialmente por causa da influência do documento Gaudium et Spes (A Igreja no Mundo Moderno). Isso aconteceu na Conferência de Medellín (1968), quando o Bispo Marcus Gregorio McGrath, CSC, apontou essa influência através de seu discurso "Os Sinais dos Tempos". Ele estava preparado para esse momento em função de seu treinamento teológico anterior na Europa e de sua pastoral missionária, especialmente no Chile e no Panamá. Foi sua atuação anterior na Ação Católica, entre jovens leigos, que o conduziu à teologia da ponte e que, por sua vez, seria estimulada posteriormente pelo Papa Francisco.

Palavras-chave: Teologia da Ponte; Leigos; Concílio Vaticano II; CELAM; McGrath, C.S.C.

Article received on June 05, 2018 and approved on July 28, 2018.

* Director Emeritus Institute for Church Life. He received his Sacrae Theologiae Doctor from St. Thomas University, Rome. At various times, he served Notre Dame as Instructor of Theology and Chair of the Theology Department, Founding Director of Latin American/North American Church Concerns (LANACC), and Fellow of Kellogg Institute. He coordinated the U.S. Conference Research Project on the Churches of America. An accredited journalist or invited participant at the Puebla, Santo Domingo, and Aparecida Conferences of Latin American Bishops (CELAM). Country of origin: United States of America. E-mail: rpelton@nd.edu

Horizonte, Belo Horizonte, v. 16, n. 50, p. 454-481, maio/ago. 2018 - ISSN 2175-5841 


\title{
Introduction
}

\begin{abstract}
Not infrequently, an opposition between theology and pastoral ministry emerges as if they were two opposite and separate realities which have nothing to do with each other. False opposition is generated between theological and pastoral ministry, between Christian reflection and Christian life. (Pope Francis, 2015). ${ }^{1}$
\end{abstract}

In 2013 Jorge Mario Bergoglio, an Argentinian Jesuit priest, following the resignation of Pope Benedict XVI, became the first Pope from the so-called New World, adopting the name Francis. He is also the very first Pope in history to choose the name of St Francis of Assisi; besides, he is also the very first Jesuit Pope.

Pope Francis has amazed the world by showing an authentic and bold refreshing of the papacy and what it means to be a Pope. A very important element in this process is the theology underlying his actions. This element of Pope Francis's theology for the time being has not been receiving so much attention from Vatican analysts, Vatican journalists, and religious scholars with research focus on contemporary Roman Catholicism.

In this article, besides the presentation of my personal memories, I would like to present the idea of "bridge theology" as a key concept to understand Pope Francis's actions. According to Rafael Luciani (2017), ${ }^{2}$ "bridge theology" emphasizes dialogue in contrast with debate about issues. It can be conducive to building bridges of understanding in place of walls of separation. This "theology of the people" stresses the lived reality of the people as is present in the Jocist methodology of "seeing-judging-acting." This sense of the realidad from this methodology will be emphasized in this article.

\footnotetext{
${ }^{1}$ Part of a video address at the International Theological Conference of Buenos Aires (September 1-5, 2015), held on the occasion of the one hundredth anniversary of the founding of the Faculty of Theology in Buenos Aires. The fiftieth anniversary of the Second Vatican Council also took place at this meeting.

${ }^{2}$ More background on Pope Francis's social and political thought is given by Thomas R. Rourke (2016).
}

Horizonte, Belo Horizonte, v. 16, n. 50, p. 454-481, maio/ago. 2018 - ISSN 2175-5841 
This paper provides an example of how the CELAM regional experiences can lead to increasing styles of effective collegiality. At Medellín the keynote address of Bishop Marcos McGrath, CSC, “The Signs of the Times,” provided strong impetus for this development in Latin America.

\section{Memories of Medellin}

In 2018, the 50th anniversary of the watershed CELAM (Episcopal Conference of Latin America) Medellín Conference takes place. The theme of "reception"-by the North, Central, and South Americas-is assuming greater relevance. This began with Pope John XXIII's call for help in ameliorating the critical shortage of clergy in Latin America during the early 1960s. Speaking in the name of the Pontifical Commission for Latin America at the University of Notre Dame in August of 1961, Monsignor Agostino Casaroli appealed for ten percent of religious to serve in Latin America (HURTEAU, 2013).

While this call for assistance in Latin America came at Notre Dame, its response came from many places. In this article we will give primary attention to the responses from two religious of the Congregation of Holy Cross: Archbishop Marcos Gregorio McGrath and myself, Fr. Robert Pelton. We were classmates throughout our religious formation and our graduate studies in Rome in 19531954 .

Particularly during the last five years of his life, Archbishop McGrath and I had a strong personal and pastoral bond as companions in Holy Cross. My provincial at that time requested that I visit Archbishop McGrath at regular intervals to be of support to him. For me, this was an honor and I continued to learn much about his commitment to the role of the laity in a post-Vatican II Church. 
There was a close similarity in our backgrounds from the University of Notre Dame and from the Congregation of Holy Cross. We both had been lay students at Notre Dame. I began my studies in 1939 with Mark following in 1941. We both had been influenced heavily by two Holy Cross mentors, Fr. Louis Putz and Fr. William Cunningham.

\section{Undergraduate Years at Notre Dame}

One of the most attractive aspects of the university was the classes in religion conducted by Fr. Louis Putz. Fr. Putz had arrived from Germany and had spent years in France. He firmly believed in Canon Cardijn's "intersection of prayer and action." Joseph Cardijn was the founder of the Young Christian Workers movement in Belgium, and he was the originator of the see-judge-act method known as the Jocist Method. Fr. Putz also brought the beginnings of the Nouvelle Theologie of France, which included a growing awareness of the role of the Catholic laity in the Church. Of special interest was Fr. Yves Congar (1953; 1957), who would later become the leading ecclesiologist of Vatican II, giving special attention to the laity.

Bernie Bauer and his wife Helene began the American Young Christian Students in 1940. This was when Mark and I began our involvement in YCS.

From the beginning of their relationship, Fr. Putz showed a special interest in young Mark McGrath. With good reason, he saw in Mark a strong potential for future ecclesial leadership. Fr. Putz believed that Mark had seen the face of Jesus Christ in the poor and suffering people of Latin America, just as he (Fr. Putz) had seen Jesus in the faces of the poor in the slums of Paris. 
Mark and I both entered the congregation's novitiate in 1943 and graduated from Notre Dame in 1945. We studied theology at Holy Cross College in Washington, D.C., and were ordained to the priesthood in 1949.

\section{Graduate Studies}

I was sent to Rome aboard the Ile de France in 1950 to study for my licentiate and my doctorate. In Paris, I joined my good friend and classmate, Fr. Mark McGrath. Mark had spent a fruitful year in France where he came into close contact with the new thinkers of northern Europe, particularly at the Catholic Institute in Paris. At a later time in his life, Mark recalled the challenges he met while doing his graduate study:

It was not until I found myself buried under in Paris and later in Rome, in this very demanding work which consumed four and a half years-of studies, research, and preparation for the dissertation -that I understood the seriousness of that question. ${ }^{3}$ I learned the techniques of research, but more importantly, I developed a method and rigor for theological reflection, which later would be a precious gift for me. . . . I had the opportunity to come in contact with the great thinkers and theological currents of Europe (Congar, de Lubac, Rahner, Guardini, the biblical and liturgical movements), as well as with the philosophical movements (personalism, Christian humanism) which were stirring at the time and which laid the groundwork for the Second Vatican Council. (MCGRATH, 1994). 4

Upon meeting in Rome, we went to the large Holy Cross House on Via Aldrovandi. There we were to experience a plethora of languages: Italian was the language of the country, the house language was French, classes were taught in Latin, and there was a Hebrew requirement for graduate students. Never having been to Europe before, I nevertheless felt at ease with the Italian people. Not surprisingly, Mark was very diligent in his work, and he took full advantage of Rome's many opportunities. I appreciated the time to interiorize many writings,

\footnotetext{
${ }^{3}$ This was a response to his superior's question about whether he was able to spend many long hours in a chair.

${ }^{4}$ Archbishop McGrath, upon receiving the highest honors from the mayor of Panama City on February 25, 1994.
}

Horizonte, Belo Horizonte, v. 16, n. 50, p. 454-481, maio/ago. 2018 - ISSN 2175-5841 
especially the Summa of Saint Thomas Aquinas. I came to know and respect the Dominicans, particularly Fr. Paul Philippe, O.P., who directed my doctoral thesis. He later became a cardinal.

As the academic year of 1951 began, additional space was needed for Holy Cross seminarians and it was necessary for us to move to the Collegio dell'Anima, a residence for German priests that offered room and board to non-Germans. Mark and I were the only priests from the United States. A number of the German priests had been prisoners of war in the United States during the recent Second World War. Many of them would become bishops upon their return to their own country.

The program leading to our licentiates was primarily an in-depth study of the Summa Theologica of Saint Thomas Aquinas, in which I found profound meaning as well as many opportunities to translate its principles into daily practice in my future ministries.

The academic superiors at Notre Dame asked me to finish my studies by the autumn of 1953. Mark was granted more time, and this proved very helpful for the work he would later assume. Even then, he was being prepared for greater Church responsibilities. He would be ready for them.

We were awarded our licentiates in the spring of 1951. The focus of my doctoral study was the laity in the Church and I chose as my thesis topic, "A Thomistic Conception of the Spirituality of the Catholic University Lay Student.” This dissertation would later be published in book form. Yves Congar, Paul Philippe, and Garrigou La Grange were major influences on me.

I completed my doctoral dissertation in the autumn of 1953. I defended my thesis on December 17, 1953, was awarded my S.T.D., and was given a private audience with Pope Pius XII-all on the same day! It was my fourth audience with the Holy Father. 
Mark's doctoral dissertation was entitled "The First Vatican Council and the Evolution of Dogma." It received the highest distinction and earned him a doctorate magna cum laude. It is hardly surprising that after graduate school he was assigned to a Holy Cross mission in Chile. I was asked to teach at the University of Notre Dame.

\section{McGrath: From Rome to Chile}

I have been acquainted with Chile since I first arrived in this land in September of 1939. I have worked as a priest since April of 1953. I say it all when I say that I feel Chilean. . . . For these personal and pastoral reasons, it is in sorrow that I leave Chile. I leave my work as Dean of the Faculty of Theology at the Catholic University, with many projects recently begun and hoping there will be no shortage of hands to carry them out. I leave my advisory position to the social action project of Saint George's after seven years, trusting in the interest of the fathers of Saint George College in this work and in the capacities of the new advisor. (MCGRATH, 1961). 5

He who was determined to "walk the path of the will of God" was pressed to break the ties of close friendships and rich and fertile pastoral work. From the earliest days of Mark's priesthood in Chile, his mind was swirling with numerous projects. Despite some anxieties, he began an active and growing apostolate which prepared him well for his future responsibilities: three years of service as rector of his congregation's seminary; professor and prefect of religion at Saint George's College; founder of Saint George Social Action; seven years as professor of theology at the Catholic University of Chile, including three years as Dean of the Faculty of Theology; and founder and editor of the magazine Theology and Life.

When Fr. McGrath returned to Panama in 1961, he was appointed as an auxiliary bishop in the archdiocese of Panama. He remained there for two years until he was named the local ordinary of Santiago de Veraguas. In 1969 he returned to Panama as the archbishop.

\footnotetext{
${ }^{5} \mathrm{Fr}$. McGrath on the eve of his return to Panama in October of 1961.
}

Horizonte, Belo Horizonte, v. 16, n. 50, p. 454-481, maio/ago. 2018 - ISSN 2175-5841 


\section{McGrath: His Experience at the Second Vatican Council}

To have lived, profoundly and up close, the Second Vatican Council, was an enormous privilege. It was also a privilege to have experienced, up close, all kinds of meetings at the Vatican, and international forums, especially at the level of our great land of Latin America, as in Medellín in 1968 and Puebla in 1979, the Council, which is that of Christ for his church in today's world. [...] Those of us bishops who participated in the Council are called "Fathers of the Council." I am a father of the council; I am, as a bishop, also its son. (MCGRATH, 1986). ${ }^{6}$

In 1959, Pope John XXIII announced three changes: a Synod of the Diocese of Rome, the reform of the Code of Canon Law, and a future ecumenical council. For this last goal, he assembled a preparatory commission charged with gathering suggestions for topics the Council should discuss.

A letter arrived at the Pontifical Catholic University of Santiago. In the Faculty of Theology, before a dozen professors, Dean McGrath read this letter, but there was no great interest or excitement, due to the general feeling that Rome would not take into account the input of the church situated on the most distant corner of the continent.

Who among us would have thought, back then, that four years later, at a meeting of the Commission on the Doctrine of the Faith at the Second Vatican Council, two members of that friendly gathering of professors would be present-one as a member and the other as an expert-and that a text from the Council of Chilean Bishops would be presented as a foundation for the new plan for the church, prepared in large part by those professors of that beloved department ... and that parts of that text were destined to be precious elements of the future Dogmatic Constitution on the Church, Lumen Gentium? (MCGRATH, 1976).

Not long after he was named auxiliary bishop of Panama City (October 1961), Bishop McGrath began preparations for the trip to Rome, where he would participate in Vatican II. At the Council, participation was optional for auxiliary bishops. Bishop McGrath had originally declined to attend because he lacked the

\footnotetext{
${ }^{6}$ Archbishop McGrath, at a fundraising dinner for the Panamanian seminary in 1986.
}

Horizonte, Belo Horizonte, v. 16, n. 50, p. 454-481, maio/ago. 2018 - ISSN 2175-5841 
financial resources to cover the trip. The vicar general at the time, Monsignor Félix Alvarado Cucalón, took an interest and the Knights of Columbus assumed the expenses.

At the beginning of the first session, Bishop McGrath was elected to a position on the Council's Committee on Doctrine; he was one of three Latin American prelates elected to this body, a responsibility that meant traveling to Rome every three months throughout the years of the Council (1962-1965). As the young bishop contributed his theological training, the Council was also shaping his own future pastoral thought and action. ${ }^{7}$

In later years, Archbishop McGrath spoke of the Council as one does of a topic recalled with intense affection. He considered the Council a milestone in the life of the church. For him, the most critical period of the Council was the first stage (October 8-December 11, 1961):

Those were probably the two most decisive months for the Catholic church in modern times. It was the historical crossroads at which this church, from its highest officials, prepared itself to close four centuries of CounterReformation and definitively entered the era of "The Church in the Modern World" (MCGRATH, 1976).

In the proceedings of Vatican II, his interventions are readily observable: in On the Sacred Liturgy (De Sacra Liturgia), November 27, 1962; On the Church, chapter on the laity, October 22, 1962; On the Apostolate of the Laity (De Apostolorum Laicorum), October 1964; Pastoral Constitution on the Church in the Modern World (De Ecclesia in Mundo Hujus Temporis), November 10, 1964; On Christian Education (De Educatione Christiana), November 19, 1964; Decree on the Church's Missionary Activity (De Activitate Missionali Ecclesiae), October 11, 1965 .

\footnotetext{
${ }^{7}$ A copy of "El Pacto de las Catacumbas," an agreement made by bishops in the Second Vatican Council about how they wished to live out their pastoral leadership, can be found in the Pelton collection in the Moreau Seminary Library, Notre Dame, IN.
}

Horizonte, Belo Horizonte, v. 16, n. 50, p. 454-481, maio/ago. 2018 - ISSN 2175-5841 
As the Council continued, McGrath became its fervent apostle, giving lectures to bishops, priests, and laity in the United States, in several European countries, and in Latin America, including in Panama, first in the archdiocese as an auxiliary bishop and later in Veraguas as bishop of the diocese of Santiago. He exemplified and emphasized the energy of the Council and its double action: return to the sources (the Church ad intra) and outreach to the world (the Church ad extra).

His contribution to the Vatican in various positions of responsibility (Secretary for Non-Believers, Consultant to the Committee on the Laity, member of the Standing Committee on the Synod, member of the Pontifical Council for the Union of All Christians) constituted a powerful testimony of the direction of the church in the twentieth century. Of similar theological impact was his input at the Extraordinary General Assembly of the Synod of Bishops in October of 1969, at which it was his task to present the theological foundations of the bishops' conferences.

In the context of Latin America, his determination to bring the aims of the Council to concrete reality was shown at the Viamao Meeting in Brazil at the dawn of the conciliar age (1964); at the Extraordinary Assembly of the Conference of Latin American Bishops (CELAM) in Mar de Plata, Argentina, the theme of which, "The Church in the Development and Integration of Latin America," anticipated a topic often under discussion in these countries; and by the services he lent to the Conference of Latin American Bishops between 1963 and 1972, including his service in the offices of secretary general and second vice president.

In the historical Medellín (1968) and Puebla (1979) conferences, his participation was influential and decisive. At Medellín, he delivered the keynote address, "The Signs of the Times in Latin America." In Puebla, he was named chairman of the Central Committee on Coordination and the Joint Commission, the efforts of which resulted in a document remarkable for its depth and solid 
theological and pastoral base. His contributions were widely recognized by the Latin American bishops.

Firmly convinced of the value of the Secretariate of the Central American Bishops (SEDAC), he lent this body his support and theological and pastoral guidance. SEDAC owes to his initiative its Commission on Theological Reflection, in which theologians and pastoral ministers of the region participate.

These efforts on behalf of the life of the church earned him recognition from various North American universities as well as the University of Louvain, where in 1970 he received the title Doctor Honoris Causa in theology and delivered a lecture entitled "Theology Alive in Latin America."

The intervening years have decisively proven wrong the prediction made by Fr. Henry, S.J., a well-known Belgian theologian lecturing in Chile in 1961. The visitor told Fr. McGrath upon his designation as a bishop that his days of theological reflection had ended. The conciliar and post-conciliar years, Medellín and Puebla, as well as his service beginning in 1981 as president of the Commission on Theological Reflection of the Conference of Panamanian Bishops, were years of intense activity theologically. More importantly, they saw the translation of conciliar theology into pastoral action and daily life. In 1986, on the twenty-fifth anniversary of McGrath's ordination as a bishop, Bishop Oscar Brown noted: "During the past twenty-five years, the church in Panama has found in Monsignor McGrath a pastor carried by the very spirit of the Council."

Archbishop McGrath himself reflected on this occasion:

The great work of my life has been to guide our church in Panama in the conciliar renewal. My greatest satisfaction has been in learning, witnessing, and living this renewal with all of you. We are very far from our goal. The enormous consequences and potentialities of the Council will be manifested with the dawn and labor of generations yet unborn. But the church in Panama, thanks to so many people, represented by you [...] is in motion: conciliar, evangelical, and pastoral motion. (MCGRATH, 1976). 


\section{Medellín (1968): The First Council of the Church of Jerusalem for the Latin American Church}

The Episcopal Conference of Latin America (CELAM) was formed as the result of a conference of Latin American bishops that took place in Rio de Janeiro, Brazil, in 1955 .

The second CELAM Conference, at Medellín, Colombia, in 1968, was its first official gathering since the Second Vatican Council, which concluded in 1965. Medellín was perceived as somewhat sensational since it brought the ancient Church into the modern world. It was to achieve this through its emphasis upon the call to peace and the social dimension of justice. Because of the limited time since the Council, the preparation was not as thorough as that of later CELAM meetings.

The methodology of Medellín was to have a prepared text that was amended and changed in discussion session. This led to sixteen conclusions, which included human promotion, evangelization, and the promotion of small communities. Medellín was seen as "pentecostal" in a certain sense, in the call to lay Christians to enter into an increasingly secular society. As was the case with the Second Vatican Council, modern methods of communication were yet to be really developed at international meetings. However, a modern Pentecost had begun, and this was through the call to action heard in the initial keynote address, "The Signs of the Times in Latin America," given by Bishop Marcos Gregorio McGrath, C.S.C., the bishop of Santiago de Veraguas and second vice president of CELAM. Within this address, he dealt with the rapidity of change, increasing secularism, and economic globalization. ${ }^{8}$ His primary source for this address was Fr. M.-D. Chenu, O.P.

Bishop McGrath had spent an earlier year, right after ordination in 1949, in Paris, France. There he became acquainted with newer ecclesial elements-the

\footnotetext{
${ }^{8}$ These three sub-themes could be applied both to the Chilean Church and the other Latin American Churches.
}

Horizonte, Belo Horizonte, v. 16, n. 50, p. 454-481, maio/ago. 2018 - ISSN 2175-5841 
biblical, liturgical, and patristic-and also the need to study more carefully the historical roots of these contributions. At that time he became acquainted with Fr. Chenu and other French Dominicans in France.

\section{Puebla (1979): A Modest Step Forward}

The meeting of the Latin American bishops in Puebla, Mexico, which took place from January 27 to February 12, 1979, was the third such continental meeting. 9 The first, as mentioned above, took place in Rio de Janeiro, Brazil, in 1955. The second, held in 1968 in Medellín, Colombia, was the response of the Latin American bishops to the directives of the Second Vatican Council. Finally, the meeting in Puebla was an effort to reflect upon the lived experience of the ten years after Medellín, during which time the grassroots groups of Christians increased dramatically. The meeting in Mexico also provided an opportunity for Mexican Catholics to manifest their sustained loyalty to the Church during many years of troubles and persecution.

The theme at Puebla, "Evangelization Today and Tomorrow in Latin America," had its origin in the Second Vatican Council, particularly in the documents on the Church (Lumen Gentium), the Church in the modern world (Gaudium et Spes), and the missions (Ad Gentes). In the 1974 Synod of Bishops in Rome the theme was also evangelization, and in 1975 Pope Paul VI synthesized this and added his own insights in Evangelii Nuntiandi. In this document the Holy Father stressed that evangelization includes not only a personal response to the grace of the Lord but it also implies a deepening awareness of the need for social changes.

As Puebla opened, the bishop participants could be roughly categorized into three groups: (1) those who had interiorized the Medellín agreements; (2) those

\footnotetext{
${ }^{9}$ John Eagleson and Philip Scharper give more information on the Puebla meeting (EAGLESON; SCHARPER, 1979).
}

Horizonte, Belo Horizonte, v. 16, n. 50, p. 454-481, maio/ago. 2018 - ISSN 2175-5841 
who were distrustful of Medellín; and (3) those in between the two preceding positions, that is, those who subscribed in theory to some aspects of the Medellín documents but at the same time were uncomfortable with other parts of the documents.

John Paul II attended the meeting in Puebla and his presence was basically positive and pastoral. It was not always easy to read his influence at a particular moment. Often it was necessary to reflect upon his gestures and observations in the context of his own background, the beautiful bond that he developed with the Mexican people, and the subtle and varying influences in the background of Latin America and the conference itself. From the beginning of his visit to Mexico, John Paul II showed a great pastoral sense that became sharpened and sensitized even further during his days there.

Doctrinally, from the beginning of his stay, and particularly in his opening homily at the Basilica of Guadalupe, he made it clear that Medellín was to be the takeoff point for Puebla, and that ten years of experience since Medellín needed to be reflected upon and respected. His theological observations tended to relate directly in varying degrees to the lived reality of Latin America, whereas his observations about social issues struck right to the heart of the social needs of that continent.

Especially in the third part of his presentation at Puebla are to be found the elements of theological concern to the Holy Father. For one thing, he feared a division between the institutional Church and the popular Church. The Puebla document clearly unifies these. In pastoral practice there does not seem to be a problem when official Church leadership reaches out to the grassroots in order to give them support and direction.

The pope was also concerned lest there be "parallel magisteria" in the Latin continent in place of the one supreme teaching authority of the Church for doctrinal matters. Again Puebla unifies this question of doctrinal teaching 
authority. One wonders here what might have been the basis for concern. Might it have been that the Confederation of Latin American Religious (CLAR), with its own theological resource persons, saw it necessary to discern the pastoral and particular role of religious in that continent?

John Paul II advised against certain re-readings of scripture that could lead to a denial of-or at least being silent about-Christ's divinity due, at least in part, to a too-great emphasis upon his humanity. In the deliberations at Puebla, and in the document itself, this concern is respected. At the same time, the Latin Christologists Jon Sobrino and Leonardo Boff continued to stress the incarnational and suffering aspect of Christ in the pastoral reality of that continent, while keeping in mind what John Paul II had said.

However, it was in the area of liberation theology that John Paul II made his strongest doctrinal contribution. Drawing heavily upon Evangelii Nuntiandi, he insisted that liberation theology be strongly rooted in the scriptures and that it include all the elements of the human person. In this context, the economic aspect, while important, is seen as one element among others. The liberation theologians themselves subscribed to these views and were aware that this young and important discipline had other areas for review and development, such as "the spirituality of liberation." Contrary to some published reports, the pope did not condemn liberation theology. In fact, he contributed needed observations for its strengthening. An expression of liberation in practice consists in the lived experience of the basic ecclesial communities (CEBS). Because of the importance of these, we shall return to them in a moment.

The social influence of John Paul II in Mexico was most challenging. This possibly gives a preview of his pontificate. In a number of places in Mexico, beginning with his talk in Oaxaca to the natives, he indicated his solidarity with them, acknowledging that they were sometimes exploited and that they had a right to effective help. He referred to the obreros (workers) at Guadalajara as his companions and encouraged them in the defense of their own rights. At Monterrey 
he did the same, and in a particular way emphasized the importance of the correct treatment of Mexican emigrants to the United States. These social addresses call for a careful reading and also application to other parts of the world. They show the strength and experience of John Paul II himself, and they reflect his theological sensitivity to social issues.

Earlier in this article, reference was made to the varying mentalities of the bishop participants at Puebla. Pope John Paul II issued a call for unity among them, keeping in mind that the teachings of Medellín were to be considered as given. Before Puebla, tensions existed concerning liberation theology, the understanding of the role of the small Christian communities, and even the degree to which CELAM itself should have a type of teaching authority over other Church organizations in Latin America.

The then-secretary general of CELAM and its new president, Bishop Lopez Trujillo, favored a stronger central voice. This question would be a cause for tension in the years ahead.

Medellín had called for the establishment of small Christian communities to strengthen the pastoral efforts of the churches of Latin America. ${ }^{10}$ There has been a phenomenal increase in the number of these groups, and they express an evergreater desire to be a dynamic part of a consultative process in pastoral planning. ${ }^{11}$ In the years between Medellín and Puebla, CEBs sometimes faltered due to the lack of clear Church support or because they were used for overtly political purposes. Puebla stood strongly behind the CEBs, encouraged their even-closer union with the Church, and asked that pastoral leaders take them more seriously. These small communities have led to a strengthening and diversity of ministries and surely are the greatest contribution of Puebla to the universal Church. As they grow, we will

\footnotetext{
${ }^{10}$ In the 1974 Roman Synod, the then-president of CELAM, Cardinal Pironio, characterized "basic ecclesial communities or groups" as the "primary cells of the entire ecclesial edifice, centres of evangelization, and the most important factor of human development" (Pro Mundi Vita).

${ }^{11}$ It was estimated that there were twelve thousand observations contributed by the Chilean CEBs in the preparation for Puebla.
} 
experience a double strengthening in ministry: that of the priesthood or ministry of all people and that of the ordained priesthood itself.

How might one assess the near future of the Latin American Church in terms of the Puebla experience? CELAM is seen as a service organization to the national episcopal conferences. The manner in which this service is carried out can change tensions into opportunities for growth.

The Puebla document is one with which pastoral leaders can live and grow. In a separate statement of the bishops, entitled "A Message to the People of Latin America," Puebla's strengths are summarized: it assumes the principles of Medellín; it manifests a "preferential option" for the poor; it challenges the leaders of Latin America to build a new society; finally, it calls upon all people to collaborate seriously in facing the monumental tasks facing Latin America today.

Puebla, then, may be seen as a step forward in Latin America, with, however, the inherent tensions and contradictions that any growth entails. The Latin American Church was coming to life! ${ }^{12}$

\section{Santo Domingo (1992): A Controversial Meeting ${ }^{13}$}

In preparing for the Santo Domingo Conference, three participants decided to attend the meeting and work together: Fr. Alfred Hennelly, S.J., of Fordham University, editor of the conference proceedings; Fr. Edward Cleary, O.P., keynote presenter at the conference; and myself, an accredited journalist from the University of Notre Dame.

\footnotetext{
${ }^{12}$ Archbishop Marcos G. McGrath, C.S.C., gave a talk, "Impact of Medellín and Puebla on the Church in Latin America," at the MedellínPuebla Conference at the University of Notre Dame on 15 March 1989.

A copy of this talk may be found in the Pelton collection in the Moreau Seminary Library, Notre Dame, IN (MCGRATH, 1989).

${ }_{13}$ More information on the experiences of Bishop McGrath and other bishops at the Council can be found in McGrath's book (MCGRATH, 2000).
}

Horizonte, Belo Horizonte, v. 16, n. 50, p. 454-481, maio/ago. 2018 - ISSN 2175-5841 
At Santo Domingo, some of the delegates-particularly from the Roman Curia-strongly supported methodological changes. In particular, these critics were against employing the see-judge-act method employed by the earlier CELAM meetings. Appointed directly from Rome as a co-president of the meeting as well as a co-secretary, they were Cardinal Sodano as co-president and Cardinal Medina as co-secretary. The already prepared consultative document was rejected by Cardinal Medina. When Fr. Hennelly shared his "Report from the Conference," we agreed that it was an accurate appraisal of the experience. We republish it herein with permission. (HENNELLY, 1993, p. 24-36. ${ }^{14}$

\section{The Synod for the Americas (1997)}

As the experience of the 1992 Santo Domingo CELAM meeting indicated a malfunctioning of that gathering, the pope and a number of his advisors felt that the solution to the many problems could be achieved through a Synod for the Americas. This would include bishops from all of the Americas, and it would be held in Rome. Even Archbishop Luciano Mendes of Brazil stated that it could develop into a Magna Carta for the Church of the Americas. It was Archbishop Mendes together with Bishop Marcos McGrath, C.S.C., of Panama who influenced quite strongly the progressive efforts of the CELAM conferences of Medellín and Puebla. Archbishop Mendes continued making positive contributions to the project at the 1997 synod. However, as the synod was beginning, the health and energy of McGrath were weakening.

There were learning experiences at the synod in Rome that could influence a clarification of the mission of the Church in the Americas. My own synodal experience was as a registered journalist. I also resided and shared regularly with a small Christian community from the United States. We also had a few discussions during the synod with Archbishop Oscar Rodriguez Mariaga of Honduras that

\footnotetext{
${ }^{14}$ The photocopied "A Report from the Conference" goes after this paragraph.
}

Horizonte, Belo Horizonte, v. 16, n. 50, p. 454-481, maio/ago. 2018 - ISSN 2175-5841 
proved to be of great assistance. He was later to become a member of the team of cardinals who advise Pope Francis.

The proximate preparations included the choice of the theme for the synod, “The Encounter with the Living Jesus Christ: The Way to Conversion, Communion, and Solidarity." This led to the outline, which in turn became the Instrumentum Laboris (the working paper for the synod).

The synodal participants had returned to a consultative process. This was a positive move! From this developed the three special themes of the synod: economic justice, solidarity, and evangelization. This would imply new evangelization, better collaboration, and economic justice.

- Economic justice: Was there to be a continuing preferential option for the poor? What was to be done with the increasing challenge of economic liberalization? What was the role of the social teaching of the Church in the light of these issues? What was the challenge of internal corruption in the governments of the Americas?

- Solidarity: This was key, especially in the growing acceptance of lay ministry and in the form of the emerging small church communities. There was also a growing awareness of indigenous rights. This respect for the appropriate role of the indigenous continues in Church practice. However, much remains to be done.

- Evangelization: Following through from the theology of Vatican II, the Latin American pastoral meetings up to this time had worked hard to discover new methods of evangelization. One of these methods worked through an increased ecumenism. This was and continues to be challenging in the mission of the Church. 


\section{Aparecida (2007): The Second Council of Jerusalem for the Latin American Church}

As the health of Pope John Paul II became quite fragile, it was decided that the next CELAM meeting should be in Latin America. Finally Aparecida, Brazil, was chosen. ${ }^{15}$ This was a blessed choice!

For the pastoral ministers who had been deeply moved by the Medellín and Puebla conferences, the possibility of this spirit being renewed was good news! Cardinal Oscar Rodriguez Mariaga of Honduras was to be a very positive enabler of this restoration.

I wish to quote here from the opening observations of my book, Aparecida: Quo Vadis?:

Having participated in the Second Vatican Council and in all of the CELAM conferences since Vatican II as an accredited journalist, I was delighted to be selected as an observer at CELAM V, the Fifth General Conference of the Bishops of Latin America and the Caribbean, held in Aparecida, Brazil, during 13-31 May 2007. (PELTON, 2008, p. 25).

Significantly, the bishops adopted the inductive "see-judge-act" method of discernment that proved so fruitful at Medellín and Puebla, whereas the 1992 Santo Domingo Conference employed a deductive and more theoretical methodology. CELAM V unequivocally endorsed and expanded three key concepts of the Latin American Catholic Church: the preferential option for the poor, ecclesial base communities (CEBs), and opposition to structural sin within the modern context of globalization and neo-liberal economic models. It did so in an enlightened and collegial manner that may diminish the controversy that has sometimes arisen from popular misunderstanding of these principles.

Small ecclesial communities received an endorsement that underscored an inclusiveness that always existed in reality, but was not universally perceived in

\footnotetext{
${ }^{15}$ For more information on CELAM V at Aparecida, see CELAM (2008) and Aparecida (2007).
}

Horizonte, Belo Horizonte, v. 16, n. 50, p. 454-481, maio/ago. 2018 - ISSN 2175-5841 
terms of their relationship with the institutional Church. The "preferential option for the poor" was expanded at Aparecida to become the "preferential and evangelizing option for the poor," making it clearer that the option is not solely a matter of socioeconomics. In a concrete demonstration of the necessity for and potential of that preferential and evangelizing option for the poor, the bishops issued a statement to the leaders of the G-8 nations, calling for the elimination of extreme poverty from all of the world's nations before 2015, making that goal "one of the most urgent tasks of our time" and one that is "inseparably linked with world peace and security." The bishops also criticized "environmental aggression" against the Amazon rainforest, warning that Amazonia-which replenishes much of the world's atmospheric oxygen supply, contains twenty percent of the world's fresh unfrozen water, and nourishes thirty-four percent of the world's forests-will cease to exist within thirty years if present patterns of corporate, profit-driven destruction continue.

Many bishops displayed acute concern about the challenges posed by globalization, rapid urbanization, the changing roles of family and youth, and the demand for real dialogue with the indigenous and African-American communities-despite the lack of concrete action in these areas. They also recognized the need for greater decision-making roles for women in the Church and for greater clarity on the roles of ministry and the laity.

That the bishops are now focusing more attention on these issues than at any other time in CELAM's history suggests their deepening understanding of the full scope of Medellín and Puebla and their growing adaptation of the mandate of promoting social justice to address the demands of present realities. Optimism about the full realization of Vatican II was strong in the 1970 sut it gradually receded throughout much of Latin America as Pope John Paul II's episcopal appointments rarely challenged the status quo maintained by the national security states of that era. 
All of these efforts were influenced by "the signs of the times" presentation by Bishop Marcos McGrath at Medellín. The rapidity of these changes, including secularism and socioeconomic changes, were rushing forward.

In order to better understand the changes, it is important to not only be conscious of the rapidity of change but also to recall the past conciliar objective of CELAM. With this in mind, it is helpful to look at the three recommendations of CELAM V and their fulfillment today. The following are taken from Aparecida: Quo Vadis?

The preferential option for the poor (GUTIÈRREZ, 2008, p. 71-92):

- There is a call to discern the signs of the times in the Aparecida document.

- There is a reaffirmation of the preferential option for the poor, and a commitment to social justice.

- An inductive methodology should be used in achieving these objectives, unlike Chile today, where the option for the poor is acknowledged more in theory than in practice.

Ecclesial base communities (MARINS, 2008, p. 93-99):

- At the time of Aparecida, these communities were still alive, but in Chile today they have lost leadership.

The ethical challenges of secular and economic globalization (BARTELL, 2008, p.101-112; ECHEVERRIA, 2008, p. 113-121):

- In Chile today we experience an impressive material development, but at what cost of Chilean culture, customs, and religion?

- The indigenous issue of the Mapuche Indians in Chile is very much in the awareness of the Chilean pastoral leadership, but this will call for further development. This is especially true in light of the new potential leadership of the country. 
In its earlier history, during the final years of Vatican II (1962-1965) and the years after the Pinochet regime (1973-1990), the Chilean church leadership showed strong pastoral leadership that gained the respect of key Catholic leaders. During the last session of Vatican II in 1965, while working with Cardinal Suenens, I became aware of the close working relationships between the ecclesial leaders of the southern cone of Latin America and the ecclesial leaders of northern Europe: France with Congar, Belgium with Suenens and key faculty from Louvain, the German Rahner, and others. These experts met so regularly both during and after the Council that some lightly referred to "the council of Louvain."

I first went to Chile in 1964. In 1965, I was invited by Cardinal Suenens to work in an advisory capacity. In March of 1966, I was named by Cardinal Silva as Episcopal Vicar for Religious Institutes of the Archdiocese of Santiago, Chile. This appointment lasted until 1972, when I was called back to the United States. This was a golden moment of the Chilean Church. It was an honor and privilege to be part of that historical period.

\section{The Future of the Chilean Catholic Church: A Roadmap for the Future}

The fifth General Conference of Aparecida had proved to be successful, and it had shown that the institutional Church is able to execute at the regional level while remaining in a constructive relationship with Rome.

However, is this in fact what happened in Chile as the country moved into the post-dictatorship era? As we saw in Chile during the Pinochet years, the chief resistance came from the pastoral leadership of the Catholic Church. In the midst of great suffering, the Catholic Church paid a steep cost in lives and it gained real transparency and acceptance. This was the Chilean Church of Cardinal Raul Silva, Monsignors Manuel Larrain and Enrique Alvear, etc. It was a Church whose pastoral leaders had dialogued regularly with Catholic Church intellectual leaders of northern Europe before, during, and after the Second Vatican Council. These

Horizonte, Belo Horizonte, v. 16, n. 50, p. 454-481, maio/ago. 2018 - ISSN 2175-5841 
leaders included notable names such as Yves Congar, O.P., Karl Rahner, S.J., and Leo Joseph Cardinal Suenens. However, as the Chileans moved ahead, something threatening was taking place: the Chileans were starting to lose their special spiritual fire. Why might this be taking place? Had they become exhausted after their courageous resistance to the dictatorship? Had the quality and style of the Church leadership changed since Aparecida? What was the role of the Christian laity in light of the Council? As I said at the end of Aparecida: Where are you going?

Also what had happened to the solid professional work of COPACHI that was later to publish the Ford study from the University of Notre Dame, a study on human rights that had influence throughout the world, especially in South Africa and Guatemala?

\section{The Congar Factor}

Early in this article, we referred to the influence of the theology of Yves Congar, O.P., in an increasing understanding of the role of the laity in the initial development of Catholic Action. Was there evidence that this actually took place in the case of Chile, Guatemala, and other Latin American countries?

Following from Aparecida, there were other challenges to be met. This was true not only for Chile but also for other post-Vatican II Churches in Latin America.

We should return to CELAM II-the dynamic conference at Medellín. At that time, Bishop Marcos McGrath, C.S.C., in the opening keynote address, had predicted the "signs of the times":

1) the rapidity of change that was to take place in the Church of Latin America,

Horizonte, Belo Horizonte, v. 16, n. 50, p. 454-481, maio/ago. 2018 - ISSN 2175-5841 
2) the marked increase of secularism in the Latin American Church, and

3) the economic globalism that would likely take place.

Evidence demonstrates that these are in fact taking place.

There is also the important Medellín contribution of the challenge of "institutionalized violence." This is a step beyond personal violence that can include business concerns, political parties, and even religious groups. Another possible way of expressing this could be the difference between personal and social sin. Institutions can sin socially.

Now let us return to the January 2018 "roadmap," which includes the challenging visit of Pope Francis to Chile. The international press was quite aware of the scandal awaiting the visit of Pope Francis. It had to do with the questioned procedure of naming the local ordinary of Osorno, in southern Chile.

In his news release of February 26, 2018, Robert Mickens, a Vatican journalist, states that the decision to appoint Juan Barros as the bishop of Osormo, Chile, has been strongly criticized by a number of Chilean laity and bishops. The critics especially believe that the voices of the laity were not heard. Cardinal Sean O’Malley of Boston stated publicly that there was a lack of due process in this case. Consequently, Pope Francis has appointed Archbishop Charles Scicluna of Malta to study the details of the present criticism and then to make his recommendation. From this study, journalist Mickens personally believes that Bishop Barros will be required to step down from the bishopric of Osormo, Chile. He also is convinced that the "footprints" of the two prelates Sodano and Medina may appear in the current review of this important issue.

The "protectors of the institution" are losing influence. In view of this likelihood, what seems to be an appropriate agenda for the Catholic Church of Chile and CELAM?

Horizonte, Belo Horizonte, v. 16, n. 50, p. 454-481, maio/ago. 2018 - ISSN 2175-5841 
- Discern carefully the role of the laity in the Church in accord with the theology of the laity as presented by Yves Congar, O.P., the special ecclesiologist of the Second Vatican Council.

- Determine why the role of small Christian communities has radically diminished in the Chilean Church in contrast with the other Catholic Churches of Latin America.

- Pray and reflect to determine reasons for the breach between its own rich community development and its present emphasis on individual material success.

\section{Conclusion}

In light of everything discussed in this article, here are two more questions to be considered:

1) Aparecida: Quo Vadis?: How should its recommendations be applied now?

2) Is this the time to support the study of the clear proposal of the Italian historian Silvia Scatena: CELAM could be the "lesson" of a regional experience in searching for forms and styles of effective collegiality? This might be an invitation to Latin American pastoral leaders to welcome those who have other tools to search for forms of effective collegiality in the prospect of building a communion of regional churches (SCATENA, 2017, p. 266-288; FAGGIOLI, 2018).

Let us now walk together on the bridge with the Chilean Church and the other Latin American Churches. And when for the very first time in our history we have a Latin American Pope, and in the year of the $50^{\text {th }}$ anniversary of the Medellín Conference, it is highly opportune to consider the idea of "bridge theology" and its role in the pastoral action of the Catholic Church, not only in Latin America, but everywhere. 


\section{REFERENCES}

Aparecida: Documento Conclusivo. Bogotá: Consejo Episcopal Latino-americano, CELAM, 2007.

BARTELL, Ernest, C.S.C. Aparecida and Global Markets. In: PELTON, Robert S. (Ed.). Aparecida: Quo Vadis? Scranton. PA: University of Scranton Press, 2008. p. 101-112.

CELAM, Secretaría General del. Testigos de Aparecida. Bogotá: Consejo Episcopal Latino-americano - CELAM, 2008.

CONGAR, Yves. Jalons pour une théologie du laïcat. Paris: Éditions du Cerf, 1953. [Reprinted in English as Lay People in the Church. London: Bloomsbury, 1957].

EAGLESON, John; SCHARPER, Philip (Ed.). Puebla and Beyond. Translation: John Drury. Maryknoll, NY: Orbis Books, 1979.

ECHEVERRIA, Javier Maria Iguiñiz. Globalization and Economics at Aparecida. In: PELTON, Robert S. (Ed.). Aparecida: Quo Vadis? Scranton. PA: University of Scranton Press, 2008. p. 113-121.

El Pacto de las Catacumbas. Pelton Collection, Moreau Seminary Library, Notre Dame, IN.

FAGGIOLI, Massimo. Lost in Transition: Francis, Benedict XVI, the Unfinished Conclave. Commonweal Magazine website, 3 April 2018. Available at:

<https://www.commonwealmagazine.org/lost-transition>. Accessed on: 17 June 2018.

GUTIÈRREZ, Gustavo, O.P. The Preferential Option for the Poor at Aparecida. In: PELTON, Robert S. (Ed.). Aparecida: Quo Vadis? Scranton. PA: University of Scranton Press, 2008. p. 71-92.

HENNELLY, Alfred T., S. J. A Report from the Conference. In: HENNELLY, Alfred T. (Ed.) Santo Domingo and Beyond: documents \& commentaries from the historic meeting of the latin american bishops' conference. Maryknoll, NY: Orbis Books, 1993. p. 24-36.

HURTEAU, Robert. A Worldwide Heart: the life of father john j. Considine. Maryknoll, NY: Orbis Books, 2013.

LUCIANI, Rafael. Pope Francis and the Theology of the People. Maryknoll, NY: Orbis Books, 2017.

MARINS, Jose. Base Communities, a Return to Inductive Methodology. In: PELTON, Robert S. (Ed.). Aparecida: Quo Vadis? Scranton. PA: University of Scranton Press, 2008. p. 93-99. 
MCGRATH, Archbishop Marcos G. Mensaje Magazine, special issue on Vatican II, Chile, 1976.

MCGRATH, Archbishop Marcos G., C.S.C. Impact of Medellín and Puebla on the Church in Latin America. Medellín-Puebla Conference at the University of Notre Dame, 15 March 1989. Pelton Collection, Moreau Seminary Library, Notre Dame, IN.

MCGRATH, Monseñor Marcos G., C.S.C. Cómo vi y viví el Concilio y el Postconcilio: el testimonio de los Padres Conciliares de América Latina. Bogotá: CELAM-Paulinas, 2000.

PELTON, Robert S. Medellín and Puebla: Dead or Alive in the 21st Century Catholic Church? In: PELTON, Robert S. (Ed.). Aparecida: Quo Vadis? Scranton. PA: University of Scranton Press, 2008. p. 25.

Pro Mundi Vita. Bulletin from Rome, 62.

ROURKE, Thomas R. The Roots of Pope Francis's Social and Political Thought: from argentina to the vatican. Lanham, MD: Rowman \& Littlefield, 2016.

SCATENA, Silvia. From Medellín to Aparecida. In: SPADERO, Antonio, S.J.; GALLI, Carlos María (Ed.). For a Missionary Reform of the Church: the "civiltà cattolica" seminar. Mahwah, NJ: Paulist Press, 2017. p. 266-288. 